\title{
Upper and lower limb functionality and body mass index in physically active older adults
}

\author{
Funcionalidade de membros superiores e inferiores \\ $e$ indice de massa corporal de idosos ativos
}

\author{
Juliana Molinari Tecchio, Cristiane Gessinger*
}

Centro Universitário Metodista (IPA), Porto Alegre, RS, Brazil

\begin{abstract}
Introduction: Aging leads to sarcopenia and functional capacity decline, compromising upper (UL) and lower limb (LL) performance of activities. Body mass index (BMI) is an important parameter for the assessment of health conditions in older adults, especially with regard to obesity, since it leads to functional limitations in terms of mobility and task performance. Objective: To investigate the potential association between UL and LL functionality and BMI in physically active older adults; and to characterize this population with regard to BMI and UL and LL functionality. Methods: The data were collected between August 2013 and April 2014. The sample comprised 371 physically active older adults. This study used secondary data from the program "PET Saúde IPA/SMS". The program interviewed older adults living in areas comprised by the Third Family Health Unit of a neighborhood in Porto Alegre/RS. This paper used questions from the "Instrumento de Avaliação Multidimensional Rápida da Pessoa Idosa" (Instrument for Rapid Multidimensional Assessment of Elderly People, in English) that had to do with UL and LL functionality, weight, height and BMI. Results and Conclusion: There was no association between UL and LL functionality and BMI in physically active older adults. More than half of the sample was overweight. Most participants had functional UL and LL. While occupation, self-perception of health as "good" and "very good", and physical activity were found to be associated with LL functionality; regular physical exercise was found to be associated with UL and LL functionality.
\end{abstract}

Keywords: Aged. Body Mass Index. Physical Therapy. Motor Activity.

\footnotetext{
* JMT: BS, e- mail: julianamtecchio@hotmail.com

CG: MS, e- mail: cristiane.gessinger@metodistadosul.edu.br
} 


\section{Resumo}

Introdução: O avanço da idade leva à sarcopenia havendo perda da capacidade funcional, com prejuízos na execução de atividades de membros superiores (MSSs) e inferiores (MsIs). O Índice de Massa Corporal (IMC) é importante parâmetro para a avaliação das condições de saúde do idoso, principalmente quanto à obesidade que dificulta a mobilidade e execução de tarefas. Objetivo: Verificar a possível associação da funcionalidade de MsSs e MsIs com o índice de massa corporal de idosos ativos e conhecer o perfil desta população quanto ao sobrepeso, baixo peso e eutrofismo, bem como da funcionalidade de MsSs e MsIs. Métodos: A coleta ocorreu de agosto de 2013 à abril de 2014 com amostra de 371 idosos ativos. Esta pesquisa utilizou os dados secundários do PET Saúde IPA/SMS, que entrevistou idosos residentes na área adscrita à Unidade 3 da Saúde da Família de um bairro em Porto Alegre/RS. Foram selecionadas as questões do Instrumento de Avaliação Multidimensional Rápida da Pessoa Idosa referentes à função de MSSs e MsIs, peso, altura e IMC. Resultados e Conclusão: não houve associação da funcionalidade de MsSs e MsIs com o IMC dos idosos ativos. Mais da metade da amostra apresentou sobrepeso. A grande maioria apresentava funcionalidade de MsSs e MsIs presente. A ocupação, a auto percepção muito boa e boa de saúde e a realização de atividade física, estiveram associadas com a funcionalidade de MsIs e a realização regular de exercícios físicos apresentou associação com a funcionalidade de MsSs e MsIs.

Palavras-chaves: Idosos. Índice de Massa Corporal. Fisioterapia. Atividade Motora.

\section{Introduction}

According to the last demographic census of the Brazilian Institute of Geography and Statistics (IBGE), there are 23.5 million older adults (people aged 60 years or older, as defined by the World Health Organization [WHO]) in Brazil. This is more than double the amount registered in 1991, when there were 10.7 million older adults. The Brazilian Census also predicted that, by 2025, Brazil will have the sixth oldest population in the world, with a predominance of women (55\%) among the older population (1). These changes in the demographic pattern of the country have occurred ever since the sixties of last century, when fertility and child mortality rates started to fall $(2,3)$.

It is paramount to understand that population aging is a multifaceted process, and functionality is a factor of great impact on public health, especially in industrialized countries. The provision of care to aging people, as well as the promotion of active aging and functional capacity are some of the relevant issues that deserve attention. Functional capacity is a key research area. It serves as a benchmark for actions, policies and programs, which will be will be even more effective if they correspond to a person's perceived needs $(4,5)$.

According to the WHO International Classification of Functioning, Disability and
Health (ICF), the capacity qualifier is associated with an individual's ability to execute a task and get involved, considering his/her intrinsic limitations, in a standard environment (6). One of the goals of the (Brazilian) National Policy on Health Care for the Elderly, on its turn, is to promote, maintain and recover older adults' autonomy and independence. According to this policy, the concept of health in aging is defined based on autonomy and independence status rather than on the presence or absence of an organic disease (2).

Loss of muscle mass and muscle strength (sarcopenia) is inevitable with aging and is one of the most important physiological changes that occur in older adults. Reduction in muscle strength and muscle power, and the consequent reduction in functional mobility in older adults is due to the decline in muscle mass that is associated with aging. A $20-40 \%$ reduction in muscle strength and functional mobility is estimated in older adults aged 70-80 years (2).

All these changes are natural to this phase of life and may affect functionality. The ICF defines functioning according to physical, environmental and subjective aspects of an individual's life and health, making clear that it encompasses all body systems and functions, as well as activities and participation of an individual, both from an individual and from a social perspective, and an 
individual's positive aspects in relation to personal and environmental factors (2).

Loss of functionality is one of the main consequences of the deterioration of the musculoskeletal system. Older adults with restricted mobility display greater rates of falls, chronic diseases, dependence, depression and death. Thus, assessing sarcopenia through physical performance measures is important in order to prevent or postpone the appearance of frailty and the occurrence of mortality among older adults $(7,8)$.

The SISVAN (Food and Nutrition Surveillance System) is a valuable instrument to support health promotion actions offered to health professionals and managers of the Unified Health System (SUS) by the Ministry of Health. Its aim is to make a descriptive and analytical diagnosis of the food and nutrition situation of the Brazilian population, and contribute to assess the nature and magnitude of nutrition problems, identifying geographical areas, social segments and population groups that are most at risk of nutritional problems. The system makes possible a continuous follow-up of trends in nutritional problems, in order to plan and assess policies, programs and interventions (9).

Body mass index (BMI) is an important parameter for the assessment of health conditions in older adults, especially with regard to obesity. Obesity leads to difficulties in mobility and in the performance of tasks in daily life (10). Based on the association between disease and obesity, the SISVAN establishes the following index and classification for the assessment of the adult population: People with a BMI equal or below 22 are considered as underweight; those with a BMI between 22.1 and 26.9 are considered normal weight (eutrophic); and people with a BMI above 27 are considered overweight (9).

Older adults are considered to be healthy when they have no need of assistance or supervision in their everyday activities $(6,11)$. It should be noted that older adults' dependence on others due to functional disability and/or restriction in the performance of activities of daily living mostly leads to the need of care. This dependent-care responsibility is usually taken by a family member, more by circumstantial imposition than by choice $(12,13)$.

Given the above, the aim of this study was to investigate the potential association between upper and lower limb functionality and body mass index in physically active older adults. Hence it will be possible to get to know this population's profile with regard to BMI and UL and LL functionality.

\section{Methods}

This quantitative, cross-sectional study used secondary data from the program "PET Saúde IPA/ SMS" (Municipal Health Office), conducted from August 2013 to April 2014 at the subjects' home. The Program is called "Diagnóstico da Situação de Saúde dos Idosos Atendidos por uma Unidade de Saúde da Família de Porto Alegre" (Diagnosis of the Health Situation of Older Adults Served by a Family Health Unit of Porto Alegre).

Data collection took place in May 2014, when the baseline database of the study was ready. The population of the previous PET Saúde IPA/SMS study comprised 398 older adults who lived in areas comprised by the Third Family Health Unit of the Northeast District, Humaitá, Navegantes and Ilhas (NHNI). This area was chosen because, according to the IBGE, it ranks second in number of older adults in Porto Alegre.

This study used two of the variables assessed in the Instrument for Rapid Multidimensional Assessment of Elderly People, which is part of the Caderno de Atenção Básica da Pessoa Idosa (guidelines on the provision of basic care to older adults) proposed by the Ministry of Health and used in the baseline study. One of them measures weight and height and calculate BMI; the other assesses upper and lower limb functionality (14).

In addition, this study used other variables to characterize the sample, such as self-reported sex, age, color/ethnicity, current occupation, self-perception of health and physical exercise. All these variables were obtained from a health and socioeconomic questionnaire developed by the researchers of the baseline study.

Exclusion criteria were: data on upper and lower limb functionality left blank in the database; and data on BMI missing due to the impossibility of assessing weight and height (as in the case older adults who were bedridden or who were not able to step on a scale). Thus, only physically active older adults remained in the sample.

Quantitative variables are presented as mean and standard deviation, while categorical variables are presented in absolute and relative frequencies. The 
chi-square test of linear trend was used to associate BMI classification and self-perception of health with upper and lower limb functionality. Pearson's chi-square test or Fisher's exact test was used to determine the association between all remaining categorical variables and outcome. The level of significance was set at $5 \%(\mathrm{p} \leq 0.05)$. All the analyses were conducted using SPSS version 21.0.

This study was approved by the Research Ethics Committees of the City of Porto Alegre and the Centro Universitário Metodista IPA, under protocol number 329.465 of August ninth, 2013. All participants were informed about the purpose of the study and gave written informed consent. The baseline study sought to pursue the information on sociodemographic characteristics with minimal embarrassment to subjects and lowest risk of imbalance when stepping on the scale to measure weight. When necessary, these individuals were referred to IAPI Health Centers.

\section{Results}

The study population comprised 398 older adults. The final sample (after exclusion criteria had been applied) included 371 physically active subjects. Mean age was 74.2 years, with $70.9 \%$ females and 91.9\% self-reported white participants. Fifty-four percent reported having an occupation at the time of assessment.

Seventy-five percent self-assessed their health as "good" or "very good" and 63.3\% reported not performing physical exercise. According to the assessments, $52.5 \%$ of the sample was overweight, $39 \%$ of participants were normal weight and $8.6 \%$ were underweight (Table 1).

Table 1 - Sample characteristics

\begin{tabular}{lc}
\hline Variables & $\mathbf{n}=\mathbf{3 7 1}$ \\
\hline $\begin{array}{l}\text { Age (years) - mean } \pm \text { SD } \\
\text { Sex }-\mathbf{n}(\%)\end{array}$ & $74.2 \pm 8.6$ \\
$\quad$ Male & $108(29.1)$ \\
$\quad$ Female & $263(70.9)$ \\
Skin color - $\mathbf{n}(\%)$ & \\
White & $341(91.9)$ \\
Black & $8(2.2)$ \\
Brown & $16(4.3)$ \\
Other & $4(1.1)$ \\
\hline
\end{tabular}

(To be continued)
Table 1 - Sample characteristics

(Conclusion)

\begin{tabular}{lc}
\hline Variables & $\mathbf{n}=371$ \\
\hline Can't tell & $2(0.5)$ \\
\hline Occupation - $\mathbf{n}(\%)$ & $201(54.8)$ \\
With & $166(45.2)$ \\
Without & \\
Health self-assessment - $\mathbf{n}(\%)$ & $279(75.7)$ \\
Very good/Good & $70(19.0)$ \\
Fair & $20(5.4)$ \\
Poor/ Very poor & \\
Physical exercise - $\mathbf{n}(\%)$ & $136(36.7)$ \\
Yes & $235(63.3)$ \\
No & \\
BMI - $\mathbf{n}$ (\%) & $31(8.6)$ \\
Underweight & $141(39.0)$ \\
Normal weight & $190(52.5)$ \\
Overweight & \\
\hline
\end{tabular}

With regard to UL function, $96 \%$ of older adults were able to touch the back of the neck. As for LL function, $95.7 \%$ of participants could get up from a chair on their own. Ninety-two percent of the sample had functional limbs. Of note, 21 of the 398 potential participants were excluded from the sample because their weight could not be measured (possibly because they were bedridden) (Table 2).

Table 2 - Upper and Lower Limb Functionality

\begin{tabular}{lc}
\hline Tasks & $\begin{array}{c}\mathrm{n}=371 \\
\mathrm{n}(\%)\end{array}$ \\
& \\
\hline $\begin{array}{l}\text { Upper limb function } \\
\text { Touch the back of the neck }\end{array}$ & $356(96.0)$ \\
Palmar grip, right hand & $368(99.2)$ \\
$\quad$ Palmar grip, left hand & $368(99.2)$ \\
Lower limb function & \\
Rise from a chair & $355(95.7)$ \\
Functional capacity* & \\
With & $344(92.7)$ \\
Without & $27(7.3)$ \\
\hline
\end{tabular}

Note: *Older adults who were able to able to perform all the proposed tasks were assessed as having functional capacity.

There was no significant association between BMI and UL and LL functionality. This result evidences that neither overweight nor underweight lead to 
a decline in upper or lower limb function, which therefore refutes this study's hypothesis.

Nevertheless, this study found an association between the functional ability of rising from a chair and having an occupation ( $p=0.049)$. Thus, it is possible to infer that older adults who had an occupation had better LL function than their counterparts (Figure 1).

There was a statistically significant association between self-perception of health and the functional ability of rising from a chair $(p=0.035)$. This result indicates that older adults with better self-assessments of health also had better lower limb functionality than their counterparts (Figure 2).

This study also found an association between physical exercise and the functional ability of rising from a chair $(\mathrm{p}=0.018)$. This indicates that older adults who exercise regularly remain more functional (Figure 3).

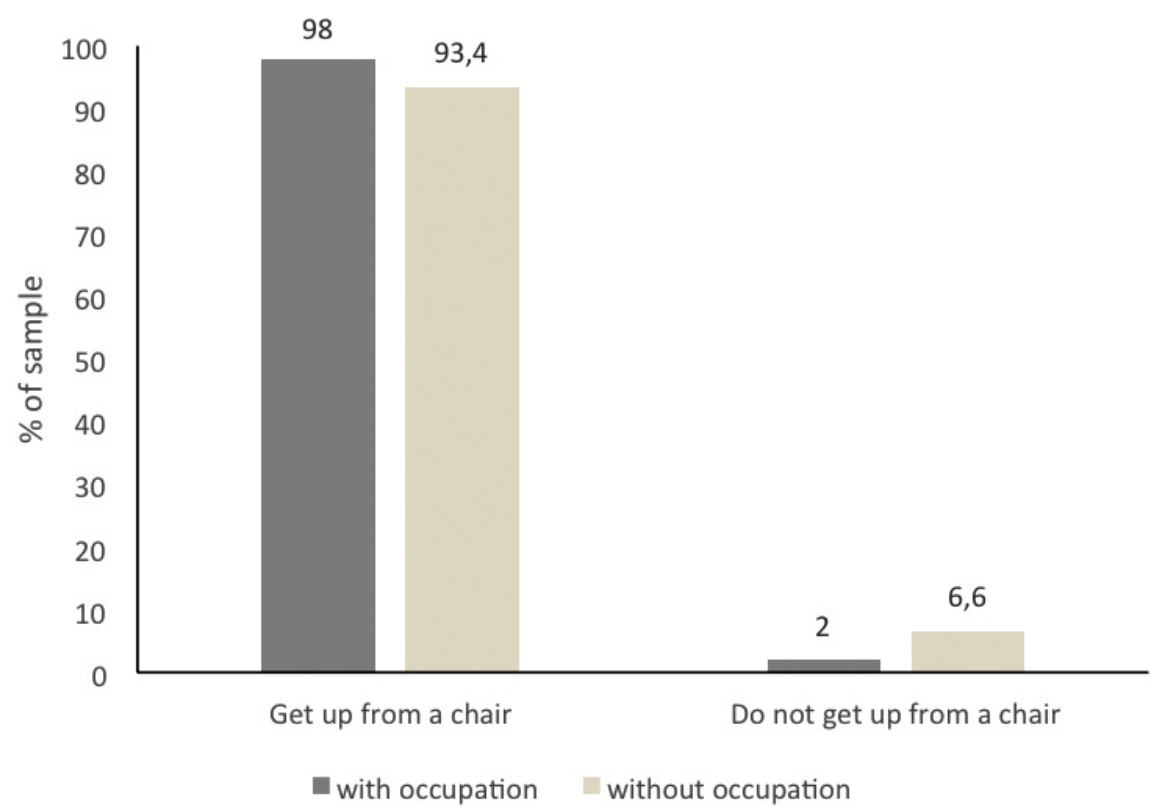

Figure 1 - Association between the functional ability of rising from a chair and having or not having an occupation.

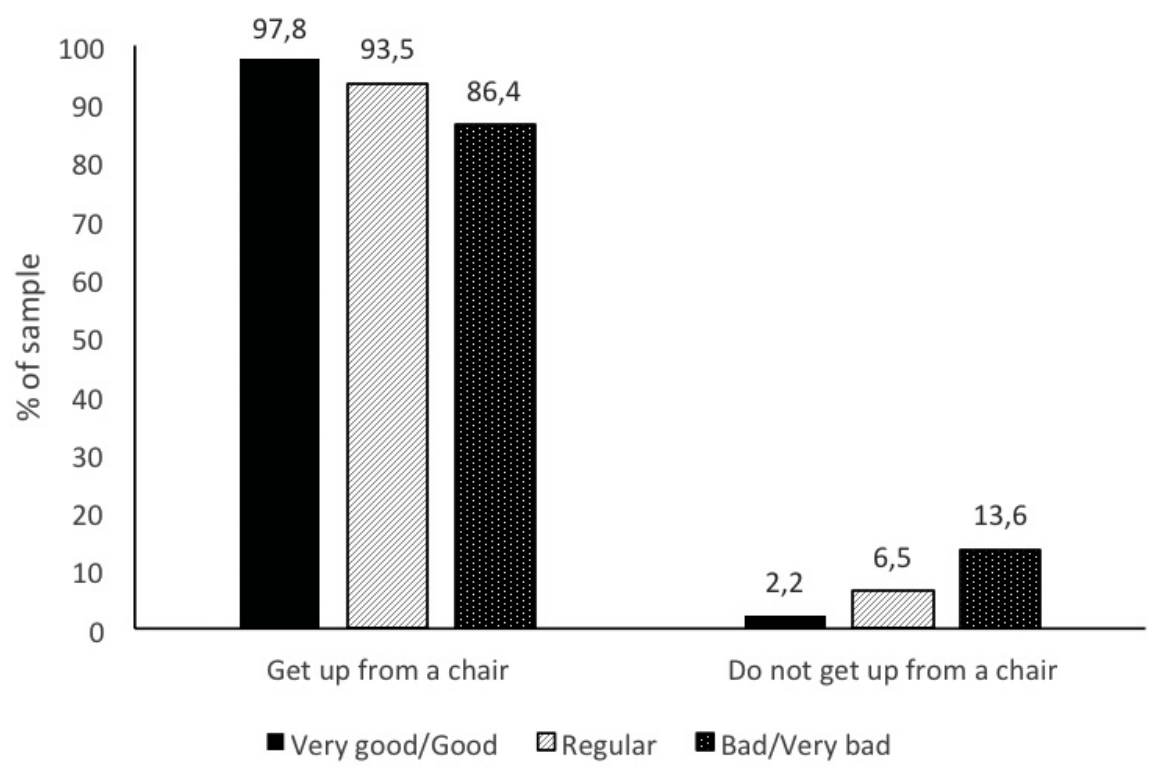


Figure 2 - Association between self-perception of health and the functional ability of rising from a chair.

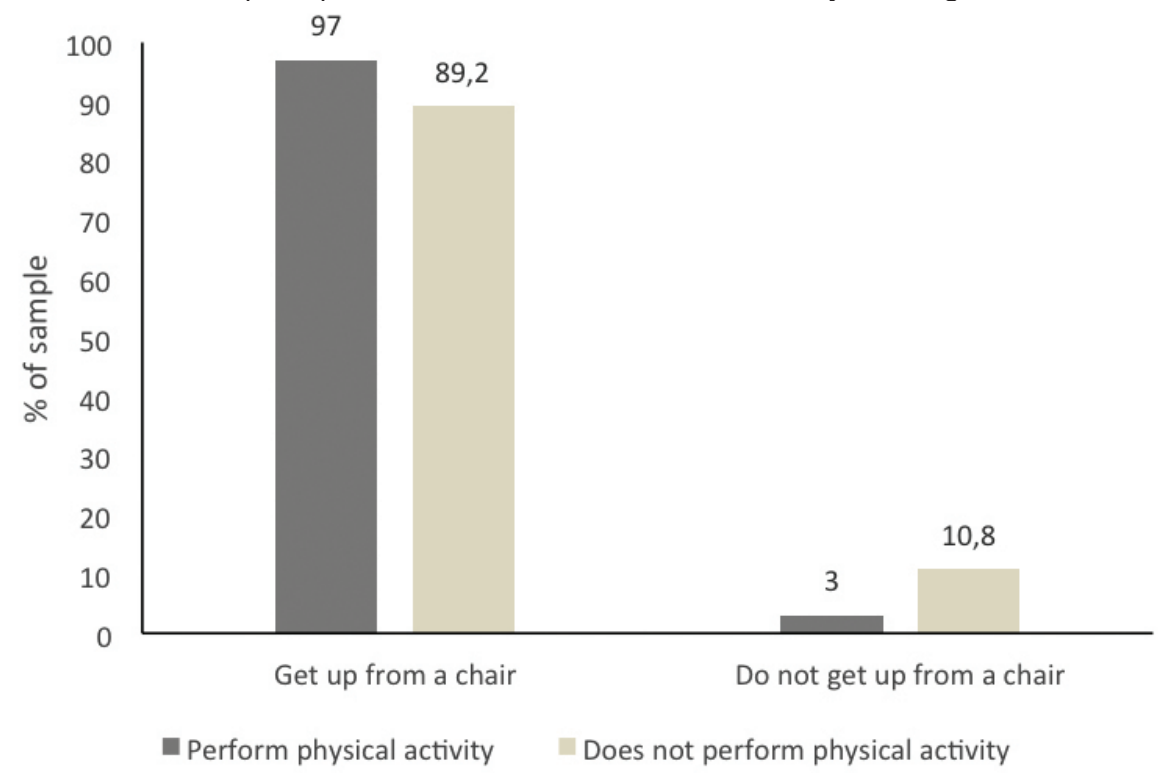

Figure 3 - Association between lower limb functionality and regular physical activity.

Those elderly people evaluated who performed physical exercise, 97,1\% performed all tasks of UL and LL and 2,9\% did not perform. Those people who did not exercise, 90,2\% performed UL and LL tasks and $9,8 \%$ did not performed.

There was an association between UL and LL functionality and regular physical activity $(p=0.025)$. This result demonstrates that people who perform physical activity remain more functional.

\section{Discussion}

This study found that more than half of the physically active older adults were overweight. This is an alarming result that demonstrates changes in the nutritional profile of older adults. A few decades ago most older adults were underweight, because the body's metabolism changes with age and older adults need to have diets of better nutritional quality. It is possible to infer that the diet of older adults has changed in recent decades to a diet that is rich in processed foods with high concentrations of fat and sugar. This may be causing overweight in older adults (15).

Obesity in older adults is becoming a serious public health problem, because the number of obese older adults is increasing sharply. Currently, about $20 \%$ of adults aged 65 years or over are obese, and this prevalence is expected to increase in the coming years. Obesity worsens age-related physical function decline, leading to frailty, compromised quality of life and dependence. Given the growing prevalence of obesity, in the near future, the most common frailty phenotype may be obese and disabled people and older adults $(15,16)$.

The absolute majority of older adults in this study had good UL and LL function, resulting in good functional capacity. This may be explained by the fact that one exclusion criterion in this study was having BMI data left blank in the baseline study database. In the case of bedridden older adults, their weight could not be measured because they were not able to step on the weighing scale. The application of this exclusion criterion resulted in a sample with functional capacity, which may be considered a research bias.

However, although the percentage of older adults with diminished functional capacity was small, the observed reduction in functional capacity can be explained by the aging process itself, which leads to a hypotrophy of existing muscle fibers. Moreover, there seems to be a reduction in satellite cells, which may compromise the ability to maintain the growth of type II fibers. A decline in the ability to maintain muscle growth and repair due to the reduction of type II fibers manifests in the form of sarcopenia. In addition, the process of remodeling of the motor unit 
may be compromised and apoptosis may increase with aging. A reduced skeletal muscle mass index is directly associated with functional impairment and physical disability in older adults. This population is at two to three times greater risk of functional impairment and physical disability (17). This loss of functional capacity leads to a reduction in physical and mental abilities that are necessary for the performance of activities of daily living $(10,18)$.

This study found that UL and LL functionality was not associated with BMI of physically active older adults. This shows that both underweight and overweight older adults displayed good functionality when performing activities of daily living. This is consistent with the study conducted by Bouchard, which compared obese and normal weight individuals and found that obesity is not associated with reduced physical capacity (19).

Another finding of this study was the association between LL functionality in the ability to rise from a chair and self-perception of health as "good" or "very good". This agrees with the study by Sposito, which associated older adults' subjective well-being with their age and functional capacity. The author found that life satisfaction does not decline with age, and, for this reason, late-life adults have flexibility and ability to adapt and maintain positive levels of life satisfaction as they get older. When older adults adapt to some kind of limitation, this adjustment is associated with aspects that promote well-being in their lives (20). Another study found that people living with activity limitations might have fewer opportunities to be satisfied with life or experience happiness, which can have a negative effect on their quality of life (21). A study by Melo also associated the effect of physical exercise on depressive symptoms among the aged. The study showed that, in addition to reducing depressive symptoms, physical exercise may also improve well-being, social contact, cognitive performance and quality of life of older adults (22).

This study also found an association between lower limb functionality in the ability to rise from a chair and currently having an occupation and being physically active. According to a study by Rodrigues, functional decline in older adults is due to some associated factors such as lack of physical activity, faulty diet and lack of weight control. The performance of physical activity by older adults, for instance, leads to improvements in functional level, cognitive performance and information processing.
Hence, physical activity seems to lead to an increase in cognitive processing speed and, consequently, to more efficient and appropriate motor responses (23, 24). The literature also states that one of the main ways of preventing, minimizing and/or reversing most physical, social and psychological declines frequently associated with aging is physical activity, as it is constantly associated with significant improvements in health conditions, such as stress, obesity, diabetes and coronary diseases control and, most importantly, improved functional capacity in older adults $(24,25)$. The study also states that having an occupation is extremely important, because family income is a key factor in the health of older adults, since they may need to use a greater number of medications, have a different diet and afford other costs generated by the physical limitation process. Additionally, due to the significant changes that have occurred lately in family arrangements, older adults may have to support/take care of unemployed or sick family members. In this context, the number of studies on the relevance of retired older adults and their role as family providers is growing rapidly (25).

In this study, regular physical exercise by older adults was associated with UL and LL functionality. Given the increasing number of older adults in the population, frailty is becoming an ever more prevalent health problem. Regular physical activity can prevent functional decline and reduce frailty symptoms (26). This result is similar to that found by Jaker that physical exercise helps preserve locomotor function and maintain muscle and bone mass, as well as functionality in older adults. The author also found that physical exercise helped decelerate the metabolic degeneration process related to chronic-degenerative diseases (diabetes, hypertension osteoporosis (27). Another study found that being physically active during leisure time was significantly associated with lower prevalence of chronic pain. The practice of physical activities by the elderly, especially during leisure time, provides opportunities for a more active, healthy and independent life, thus contributing with the maintenance of autonomy and improved quality of life (28).

It is important to differentiate between two concepts: physical activity and physical exercise. Physical activity is a generic expression that can be defined as any bodily movement produced by skeletal muscles that results in greater energy expenditure than rest; physical exercise (one of its 
main components) is an activity that is planned, structured, and repetitive and has as a final or an intermediate objective the improvement or maintenance of health/physical fitness. In this study, the terms "physical activity" and "physical exercise" have been used as two different concepts. According to a study by Cabello, higher physical activity levels are associated with greater muscle strength. Having in mind that muscle strength is associated with lower risk of disability as well as with better health, and taking into consideration the results obtained in this study, older adults should be encouraged to have an active lifestyle in order to ensure the maintenance of functional status in aging (29). The literature also shows that hippocampal deterioration precedes and leads to memory impairment in late adult life. For this reason, both from a scientific and public health perspective, strategies to combat hippocampal volume loss and protect against memory compromise have become an important topic in recent years. The study demonstrated that physical activity increases the volume of gray and white matter in the prefrontal cortex of older adults, the functioning of key nodes in the executive control network, and cerebral blood volume and perfusion of the hippocampus, thus improving learning performance $(30,31)$.

\section{Conclusion}

This study found no association between UL and LL functionality and BMI in physically active older adults. Obese, normal weight and underweight adults displayed similar functionality.

In addition, more the sample was overweight. This is an alarming result that demonstrates changes in the nutritional profile of older adults, as most of them were previously underweight. The great majority of the sample had functional upper and lower limbs.

Occupation, self-perception of health as "good" and "very good", and physical activity were found to be associated with lower limb functionality. Regular physical exercise was associated with upper and lower limb functionality.

Further studies are required to deepen the knowledge of this research topic. The results of this study indicate that the changes in the nutritional profile of the study population will increasingly affect public funds, because this population, the group that most uses health services, shall experience consequences such as overweight- and obesityrelated comorbidities.

Education in health should focus on basic education to improve eating habits of older adults and the general population. Physical exercise should be increasingly encouraged as a health promotion strategy. Brazilians need to receive comprehensive care - one requirement of the UHS (SUS) that is still not fulfilled.

\section{Acknowledgments}

Many thanks to the coordinator of the PET Saúde IPA/SMS, Alessandra Dartora, for taking the initiative to promote the implementation of the PET Saúde program at the Centro Universitário Metodista IPA.

We would also like to thank the staff of the PET Saúde IPA/SMS, who collected data through home interviews under the most extreme climate conditions of Rio Grande do Sul. A special thanks to the preceptor and nutritionist Nara Veras Guimarães, for performing nutritional assessment follow-up. We also wish to thank the older adult population of the neighborhood of Passo D'Areia in Porto Alegre, who so kindly received us and volunteered to make this and other studies possible.

Finally, we gratefully acknowledge the Ministry of Health for its support of the Pró Pet - Saúde program, whose aim is to promote the collaboration across the education, health services, and community sectors.

\section{References}

1. IBGE. Censo Demográfico. População residente, por cor ou raça, segundo o sexo e os grupos de idade - Brasil. 2013 [cited 2013 Aug 18]. Available from: htpp://www.ibge.gov.br.

2. Garcia PA, Dias JMD, Dias RC, Santos P, Zampa CC. Estudo da relação entre função muscular, mobilidade funcional e nível de atividade física em idosos comunitários. Rev Bras Fisioter. 2011;15(1):15-22.

3. Veras R. Envelhecimento populacional contemporâneo: demandas, desafios e inovações. Rev Saude Publica. 2009;43(3):548-54. 
4. Pereira JK, Firmo KCG, Giacomin KC. Maneiras de pensar e de agir de idosos frente às questões relativas à funcionalidade/incapacidade. Cienc Saude Coletiva. 2014;19(8):3375-84.

5. Fiedler MM, Peres KG. Capacidade funcional e fatores associados em idosos do Sul do Brasil: um estudo de base populacional. Cad Saude Publica. 2008; 24(2):409-15.

6. Machado FN, Machado AN, Soares SM. Comparison between ability and performance: a study on the functionality of dependent elderly individuals. Rev Latino-Am Enfermagem. 2013;21(6):1321-9.

7. Lin JH, Huang MW, Wang DW, Chen YM, Lin CS, Tang YJ, et al. Late-life depression and quality of life in a geriatric evaluation and management unit: an exploratory study. BMC Geatr. 2014;14:77.

8. Falsarella GR, Coimbra IB, Barcelos CC, Iartelli I, Montedori KT, Santos MN, et al. Influence of muscle mass and bone mass on the mobility of elderly women: an observational study. BMC Geriatrics 2014;14:13.

9. Perez AIC, Oliveira TZ, Moraes MA, Shirassu MM, Ribeiro AB, Coria S. Monitoramento do estado nutricional de usuários de Unidades Básicas de Saúde no Estado de São Paulo por meio do Sistema de Vigilância Alimentar e Nutricional (SISVAN). BEPA, Bol epidemiol. 2013;10(116):1-13.

10. Macedo GA, Costa MF, Andrade AGP, Borges Jr M, Dias VB. Correlação entre o índice de massa corporal e o teste de sentar e levantar em idosos fisicamente ativos. Coleç Pesqui Educ Fis. 2010;9(6):115-20.

11. Alves LC, Leite IC, Machado CJ. Fatores associados à incapacidade funcional dos idosos no Brasil: análise multinível. Rev Saude Publica. 2010;44(3):468-78.

12. Loureiro LSN, Fernandes MGM, Nóbrega MML, Rodrigues RAP. Sobrecarga em cuidadores familiares de idosos: associação com características do idoso e demanda de cuidado. Rev Bras Enferm. 2014;67(2):227-32.

13. Nakano MM, Otonari TS, Takara KS, Carmo CM, Tanaka C. Physical Performance, Balance, Mobility, and Muscle Strength Decline at Different Rates in Elderly People. J Phys Ther Sci. 2014;26(4):583-6.
14. BrasiL. Ministério da Saúde. Política Nacional de Atenção Básica. Série E. Legislação em Saúde. Brasília: Ministério da Saúde; 2012.

15. Villareal DT, Chode S, Parimi N, Sinacore DR, Hilton T, Armamento-Villareal R, et al. Weight Loss, Exercise, or Both and Physical Function in Obese Older Adults. N Engl J Med. 2011;364(13):1218-29.

16. Giuli C, Papa R, Bevilacqua R, Felici E, Gagliardi C, Marcellini $\mathrm{F}$, et al. Correlates of perceived health related quality of life in obese, overweight and normal weight older adults: an observational study. BMC Public Health. 2014;14:35.

17. Emerson NS, Fukuda DH, Stout JR1, Robinson EH, McCormack WP, Scanlon TC, et al. Physical working capacity at fatigue threshold (PWCFT) is associated with sarcopenia-related body composition and measures of functionality in older adults. Arch Gerontol Geriatr. 2014;59(2):300-4.

18. Santos AA, Pavarini SCI. Funcionalidade de idosos com alterações cognitivas em diferentes contextos de vulnerabilidade social. Acta Paul Enferm. 2011;24(4):520-6.

19. Bouchard DR, Dionne IJ, Brochu M. Sarcopenic/ Obesity and Physical Capacity in Older Men and Women: Data From the Nutrition as a Determinant of Successful Aging (NuAge) - the Quebec Longitudinal Study. Obesity (Silver Spring). 2009;17(11):2082-8.

20. Sposito G, Diogo MJD, Cintra FA, Neri AL, Guariento ME, Souza MLR. Relações entre o bem-estar subjetivo e a funcionalidade em idosos em seguimento ambulatorial. Rev Bras Fisioter. 2010;14(1):81-9.

21. Levasseur M, Desrosiers J, St-Cyr Tribble D. Do quality of life, participation and environment of older adults differ according to level of activity? Health Qual Life Outcomes. 2008;6:30.

22. Melo B, Moraes HS, Silveira H, Oliveira N, Deslandes AC, Laks J. Efeito do treinamento físico na qualidade de vida em idosos com depressão maior. Rev Bras Ativ Fis Saúde. 2014;19(2):205-14.

23. Rodrigues PCS, Barreiros JMP, Vasconcelos MOF, Carneiro SRM. Efeito da prática regular de atividade física no desempenho motor em idosos. Rev Bras Educ Fis Esporte. 2010;24(4):555-63. 
24. Weuve J, Kang JH, Manson JE, Breteler MM, Ware JH, Grodstein F. Physical activity, including walking, and cognitive function in older women. JAMA. 2004;292(12):1454-61.

25. Santos GS, Cunha ICKO. Avaliação da capacidade funcional de idosos para o desempenho das atividades instrumentais da vida diária: um estudo na atenção básica em saúde. R Enferm Cent 0 Min. 2013;3(3):820-8.

26. Taylor D. Physical activity is medicine for older adults. Postgrad Med J. 2014;90(1059):26-32.

27. Jarek C, Oliveira MH, Nantes WR, Ulbricht L, Mascarenhas LPG. Comparação antropométrica, força muscular e equilíbrio entre idosos praticantes e não praticantes de musculação. RBCEH. 2010;7(2):173-80.

28. Santos FAA, Souza JB, Antes DL D’Orsil E. Prevalência de dor crônica e sua associação com a situação sociodemográfica e atividade física no lazer em idosos de Florianópolis, Santa Catarina: estudo de base populacional. Rev Bras Epidemiol. 2015;18(1):234-47.
29. Cabello AG, Carnicero JA, Bouzónc CA, Tresguerres JA, Acha AA, Ara I, et al. Age and gender, two key factors in the associations between physical activity and strength during the aging process. Maturitas. 2014;78(2):106-12.

30. Erickson KI, Voss MW, Prakash RS, Basak C, Szabo A, Chaddock L, et al. Exercise training increases size of hippocampus and improves memory. Proc Natl Acad Sci U S A. 2011;108(7):3017-22.

31. Zlatar ZZ, Towler S, McGregor KM, Dzierzewski JM, Bauer A, Phan S, et al. Functional language networks in sedentary and physically active older adults. J Int Neuropsychol Soc. 2013;19(6):625-34.

Received in 03/02/2016

Recebido em 02/03/2016

Approved in 04/04/2017

Aprovado em 04/04/2017 